\title{
Interrelation between chitinase-3-like protein 1 (CHI3L1) - YKL-40, C-reactive protein and spirometry in chronic lung disease
}

\author{
Interrelația dintre chitinase-3-like protein 1 (CHI3L1) - YKL-40, \\ proteina $C$ reactivă și spirometrie în bolile pulmonare cronice
}

Romana Olivia POPEȚIU ${ }^{1,2}$, Silviu Daniel MOLDOVAN², Simona Maria BORTA ${ }^{1,2}$, Oana Lucia AMZA' ${ }^{1,2}$, Maria PUŞCHIȚA $\breve{A}^{1,2}$

${ }^{1}$ Facultatea de Medicină, Universitatea de Vest „Vasile Goldiș“, Arad, România

${ }^{2}$ Spitalul Clinic Județean de Urgență, Arad, România

\begin{abstract}
Bronchial asthma is one of the most prevalent chronic diseases in young adults. Numerous studies have investigated the association between genetic variations and expression of different asthma phenotypes, airway hypersensitivity and their inflammation including neutrophilia, eosinophilia and macrophages. Chitinase-3-like protein 1 (CHI3L1) - YKL-40 in serum is a biomarker of inflammation associated with the activity and mortality of lung chronic diseases, diseases that are characterized by inflammation and tissue remodeling. YKL-40 may be an important prognostic biomarker of patients with chronic lung disease.
\end{abstract}

Keywords: chitinase-3like protein 1, YKL-40, bronchial asthma, COPD

\section{REZUMAT}

Astmul bronșic este una dintre cele mai prevalente boli cronice la tineri. Numeroase studii au investigat asocierea dintre variațiile genetice și expresia diferitelor fenotipuri de astm, hipersensibilitatea căilor aeriene și inflamația lor, incluzând neutrofilie, eozinofilie și macrofage. Chitinase-3-like protein 1(CHI3L1)-YKL40 din ser este un biomarker inflamator asociat cu activitatea și mortalitatea bolilor pulmonare cronice, boli caracterizate prin inflamație și remodelare tisulară. YKL-40 poate fi un important biomarker de prognostic al pacienților cu boli pulmonare cronice.

Cuvinte cheie: chitinase-3-like protein 1, YKL-40, astm bronșic, BPOC

\section{INTRODUCERE}

Astmul bronșic este una dintre cele mai prevalente boli cronice la tinerii adulți și frecvența sa este în creștere din cauza factorilor de mediu, însă și factorii genetici joacă un rol substanțial în sus- ceptibilitatea astmului bronșic. Numeroase studii au investigat asocierea dintre variațiile genetice și expresia diferitelor fenotipuri de astm, hipersensibilitatea căilor aeriene și inflamația lor, incluzând neutrofilie, eozinofilie și macrofage (1). 


\section{CHITINASE-3-LIKE PROTEIN 1 - YKL-40}

Chitinase-3-like protein 1 (CHI3L1) - YKL-40 din ser este un biomarker inflamator asociat cu activitatea și mortalitatea bolilor pulmonare cronice, boli caracterizate prin inflamație și remodelare tisulară. Mecanismul exact din spatele creșterii mortalității observate la pacienții cu valori crescute ale YKL-40 în ser este necunoscut.

Limitarea fluxului de aer este factorul important în bolile pulmonare obstructive cronice (BPOC). Limitarea acestui flux de aer este ireversibilă și este recunoscut faptul că distrugerea țesutului pulmonar - ca răspuns la procesele inflamatorii din cauza expunerii prelungite la noxe, gaze, fum de țigară - este asociată cu dezvoltarea de BPOC. Boala este de obicei progresivă și este una dintre principalele cauze de deces în lume. La fel ca și în astmul bronșic, și în BPOC, concentrația plasmatică a YKL-40 a atras atenția ca biomarker de activitate a bolii, având rol în inflamație, remodelare tisulară și fibroză (3).

YKL-40 reglează factorul de creștere vascular endotelial și are un rol în inflamație, proliferare celulară și diferențiere, remodelarea matricei celulare și protecție împrotriva apoptozei (2). YKL-40 este secretat de celule din mucoasa căilor respiratorii, de exemplu neutrofile, macrofage și celule ale epiteliului respirator. Recent, a devenit tot mai evident faptul că YKL-40 joacă un rol important în bolile pulmonare inflamatorii. Concentrații crescute au fost întâlnite în plasmă, în lichidul de lavaj bronho-alveolar la pacienții cu astm bronșic, BPOC și fibroză pulmonară idiopatică. Interesant este faptul că niveluri crescute de YKL-40 în plasmă au indicat un risc crescut de supraviețuire scurtă la majoritatea pacienților cu fibroză pulmonară idiopatică. Când macrofagele pacienților cu BPOC sunt expuse la YKL-40, se produc niveluri crescute de biomarkeri inflamatori precum IL-8, MCP-1 (monocyte chemoattractant protein), MMP-9 (matrix metalloproteinase), iar YKL-40 este secretat de macrofagele alveolare când este stimulat de către TNF-alfa (tumor necrosis factor) $(4,5,9)$.

Chitinase-3-like protein 1 (CHI3L1) - YKL-40 este crescut în circulația adulților, dar și a copiilor cu astm bronșic sever. Nu se cunoaște dacă YKL-40 este implicat în inflamația căilor aeriene la preșcolari cu boli pulmonare, dar este cunoscut faptul că dezvoltarea astmului bronșic începe din copilărie, iar mecanismul biologic este puțin cunoscut. Totuși, există date recente ce arată că în cazul infecției cu rinovirusuri, atât în timpul simptomelor, cât și după vindecare, titrurile biomarkerilor sunt modificate, ceea ce reflectă un profil mo- lecular alterat, crescând astfel riscul apariției astmului bronșic (2).

\section{PROTEINA C REACTIVĂ (PCR)}

PCR (proteina $C$ reactivă) este un alt factor inflamator întâlnit la pacienții cu BPOC; valorile crescute ale PCR sunt asociate cu disfuncția pulmonară (6). Au fost efectuate studii privind relația dintre proteina $\mathrm{C}$ reactivă și importanța ei în stabilirea prognosticului în bolile pulmonare cronice. Proteina $\mathrm{C}$ reactivă este o proteină de fază acută sintetizată predominant în hepatocit ca răspuns la distrugerea tisulară și la inflamație. S-a demonstrat că valorile proteinei $\mathrm{C}$ reactive cresc atât în bolile pulmonare cronice, cât și în exacerbările din bronhopneumonia obstructivă cronică și astmul bronșic. Valoarea proteinei $C$ reactive este crescută la pacienții cu insuficiență respiratorie cronică, la cei cu FEV scăzut, dar și la fumători. Valorile crescute ale PCR au un rol predictiv în riscul cardiovascular la pacienții cu boli pulmonare cronice, însă pot scădea în cursul tratamentului inhalator sau sistemic cu corticosteroizi, terapiei cu statine și datorită exercițiilor fizice (7).

Este acceptat faptul că nivelurile plasmatice crescute ale proteinei $\mathrm{C}$ reactive sunt corelate $\mathrm{cu}$ obstrucția fluxului de aer din căile respiratorii, însă nu s-au efectuat studii de evaluare a legăturilor între proteina $C$ reactivă și alte variabile clinice privind prognosticul la pacienții cu boli pulmonare cronice. PCR poate acționa și ca agent proinflamator, activând cascada complementului, care poate fi intens proinflamator prin strânsa legătură cu fragmentul C1q al complementului. PCR activează totodată factorul NF-kB (nuclear factor kappa light chain enhancer of activated $B$ cells) din celulele endoteliale și cele mononucleare, inducând proteaze și citokine proinflamatorii cum ar fi interleukinele IL-1B, IL-6, IL-8 și IL-18. Interesant este faptul că, în context vascular, teoria apoptozică a emfizemului, PCR reprimă potențialul de reparare endotelial al celulelor stem (8).

\section{SPIROMETRIA}

Spirometria este un test al capacității respiratorii, folosit de obicei pentru a diagnostica boli precum astmul bronșic sau bronhopneumonia obstructivă cronică, dar și pentru a monitoriza evoluția acestora sau răspunsul la tratament.

Diagnosticul de BPOC se realizează prin anamneză, examenul clinic, examene biologice și este confirmat de spirometrie. Volumul rezidual și capacitatea pulmonară totală sunt crescute în majoritatea cazurilor. $\mathrm{O}$ radiografie toracică poate 
evidenția emfizem pulmonar confirmat prin computer tomograf, iar spirometria efectuată postadministrare de bronhodilatatoare este necesară pentru a confirma diagnosticul de BPOC $(10,11,12)$.

În astmul bronșic, experții medicali au recomandat de comun acord efectuarea spirometriei ca evaluare inițială, după ce tratamentul este inițiat și simptomele s-au stabilizat. Diagnosticul de astm bronșic se realizează prin anamneză, crize recurente de tuse și dispnee. La examenul fizic se poate decela wheezing-ul, iar obstrucția căilor aeriene se poate determina prin spirometrie. Măsurarea peak expiratory flow rate este recomandată pentru monitorizarea pacienților cu diagnostic de astm bronșic moderat sau sever. Spirometria rămâne esențială în diagnosticul atât al astmului bronșic, cât și al altor boli pulmonare cronice. Efectuarea spirometriei la pacienții cu risc de dezvoltare atât a astmului bronșic, cât și a bronhopneumo- niei obstructive cronice sau cu simptome respiratorii poate ajuta la detectarea cauzelor întrun stadiu incipient și poate întârzia deterioarea ulterioară $(13,14)$.

\section{CONCLUZII}

Nivelurile plasmatice ale YKL-40 sunt crescute la pacienții cu boli pulmonare cronice, dar rolul exact în progresia acestor boli rămâne încă necunoscut. Sunt necesare și alte studii prospective pentru a urmări corelațiile între YKL-40 plasmatică, alți parametri biologici și creșterea susceptibilității bolilor pulmonare cronice. Creșterea activității inflamatorii poate duce la un răspuns inflamator exagerat, iar YKL-40 poate fi un important biomarker de prognostic al pacienților cu boli pulmonare cronice.

Conflict of interest: none declared Financial support: none declared

\section{BIBLIOGRAFIE}

1. Jakob W Hansen, Simon F Thomsen, Celeste Porsbjerg, Linda M Rasmussen, LotteHarmsen, Julia S Johansen, Vibeke Backer. YKL-40 and genetic status of CHI3L1 in a large group of asthmatics. European Clinical Respiratory Journal, 2015, 25117.

2. Jang YY, Park HJ, Chung HL. Serum YKL-40 levels may help distinguish exacerbation of post-infectious bronchiolitis obliterans from acute bronchiolitis in young children. Eur J Pediatr 2017. 970-980.

3. Holmgaard DB, Mygind LH, Titlestad IL, Madsen $\mathrm{H}$, Pedersen SS, Johansen JS, Pedersen C. Plasma YKL-40 and all-cause mortality in patients with chronic obstructive pulmonary disease. BMC Pulm Med. 2013 Dec 30;13:77.

4. Letuve S, Kozhich A, Arouche N, Grandsaigne M, Reed J et al. YKL-40 is elevated in patients with chronic obstructive pulmonary disease and activates alveolar macrophages. J Immunol 2008, 181:51665174.

5. Funda Aksu, Nermin Çapan, Kurtuluş Aksu, Ruhsar Ofluoğlu, Sema Canbakan,
Bünyamin Yavuz, Kadir Okhan Akin. $\mathrm{C}$-reactive protein levels are raised in stable Chronic obstructive pulmonary disease patients independent of smoking behavior and biomass exposure. $J$ Thorac Dis. 2013. 413-422.

6. JP de Torres, E Cordoba-Lanus, C Lopez-Aquilar, M Muros de Fuentes, A Montejo de Garcini, AAquirre-Jaime, BR Celli, C Casanova. C-reactive protein levels and clinically important predictive outcomes in stable COPD patients. Eur Respir J 200; 27; 902-907.

7. GP Anderson. COPD, asthma and C-reactive protein. EurRespir J, 2006, 873-877.

8. Xingge Yang and Guangyao Sheng. YKL-40 levels are associated with disease severity and prognosis of viral pneumonia, but not available in bacterial pneumonia in children. BMC Pediatrics, 2018 18:381.

9. Johns DP, Walters JA, Walters EH. Diagnosis and early detection of COPD using spirometry. J Thorac Dis. 2014 Nov;6(11):1557-69.
10. Joo MJ, Au DH, Fitzgibbon ML, McKell J, Lee TA. Determinants of spirometry use and accuracy of COPD diagnosis in primary care. J Gen Intern Med. 2011 Nov; 26(11):1272-7.

11. Han MK, Kim MG, Mardon R, Renner $P$, Sullivan S, Diette GB, Martinez FJ. Spirometry utilization for COPD: how do we measure up? Chest. 2007 Aug; 132(2):403-9.

12. Lee TA, Bartle B, Weiss KB. Spirometry use in clinical practice following diagnosis of COPD. Chest 2006, 1509-15.

13. Celli BR, MacNee W; ATS/ERS Task Force. Standards for the diagnosis and treatment of patients with COPD: A summary of the ATS/ERS position paper. EurRespir J. 2004. 932-46.

14. https://goldcopd.org/Guidelineitem. asp?|1=2\&|2=1\&intld=989. 